\title{
Knowledge Management in Banking Industries: uses and opportunities
}

\section{Author}

\section{Jayasundara, Chaminda Chiran}

MSc (Sheffield), MACP (UK)

Senior Assistant Librarian

e-Learning Project, Main Library, University of Colombo

Sri Lanka.

\section{Contact Details}

E-Mail: chaminda@lib.cmb.ac.lk

Tell: 00-94-11-2586432/2414183

Fax: 00-94-11-2583043

\section{Abstract}

This paper reviews the prevailing literature on Knowledge Management in banking industries. The purpose of $\mathrm{KM}$ is to value to information resides in organizations resulting value addition to their tasks and ultimately to approach competitive advantage. Most common KM applications identified in the banking industries are risk management. Customer Relationship 
Management/Marketing (CRM), performance evaluation etc, Decision Support Systems (DSS), data where houses and data mining are rapidly growing techniques in this particular sector. However, most banks around the world do not use comprehensive knowledge management systems while other financial organizations in the same disciplines do.

\title{
Keywords: Knowledge Management, Banking Industries, Information Management
}

\section{What is Knowledge management?}

Before defining the Knowledge Management, it is vital to define what the Knowledge is. The Oxford Advanced learner's Dictionary says (2000:714) "knowledge: information, understanding and skills gain through education or experience". According to Barclay and Murray, (1997)

\begin{abstract}
"Knowledge has two basic definitions of interest. The first pertains to a defined body of information. Depending on the definition, the body of information might consist of facts, opinions, ideas, theories, principles, and models (or other frameworks). Clearly, other categories are possible, too. Subject matter (e.g., chemistry, mathematics, etc.) is just one possibility. Knowledge also refers to a person's state of being with respect to some body of information. These states include ignorance, awareness, familiarity, understanding, facility, and so on."
\end{abstract}

There are two types of Knowledge: explicit, which can be written down and shared; and tacit which is learnt through experience and is 
communicated person to person. Knowledge Management (KM) attempts to get the best balance between what can and should be written down and what should be shared among a community of knowledge workers.

KM can be defined in many ways since it often depends on the original position of the author. Three central themes namely Organizational Learning, Document Management and Technology, dominate the field of Knowledge Management as discovered through communication with the field specialists and surveys of the professional literature (Srikantaiah, 2000). However, some theorists have already presented a number of working definitions for Knowledge Management. According to Malhothra (2001)

"Knowledge Management caters to the critical issues of organizational adaptation, survival and competence in face of increasingly discontinuous environmental change.... Essentially, it embodies organizational processes that seek synergistic combination of data and information processing capacity of information technologies and the creative and innovative capacity of human beings".

In fact, Knowledge Management is not only about managing knowledge assets such as knowledge regarding markets, technologies, products, and organizations, which facilitates business processes to make profits, add value, etc; but also managing the processes that act upon the assets. Developing knowledge; using knowledge, and sharing knowledge; preserving knowledge are a few examples of these processes. In accordance with these, Macintosh (1999) states 
"Knowledge management involves the identification and analysis of available and required knowledge assets and knowledge asset related processes, and the subsequent planning and control of actions to develop both the assets and the processes so as to fulfill organizational objectives".

\section{Organizational context}

In the global knowledge economy, organizations are recognizing the importance of knowledge as a means to gain or sustain competitive advantage. Researchers have concluded that the only thing that is sustainable, for a successful business, in the future world is what it knows, how it uses, and how fast it can acquire new knowledge.

The purpose of knowledge management is to add value to information already held by the business organization, resulting in knowledge that will be of strategic use to the organization. Although specifics vary, knowledge management deals with expertise or human capital; general and financial management; customers, operations marketing and sales; intellectual property, technical processes and products.

Many business organizations' expenditure on KM is due to rise to over 6 percent of revenues over the next few years (Murray and Myers, 2006) because they are recognizing that they are on the threshold of a knowledge-based economic revolution (Stewart, 1997) and because leveraging knowledge, particularly tacit knowledge, is the major input to maintain competitive advantage in the future (Nonaka, 1991). If this is so then KM. is clearly a fundamental process for managing organizations in the twenty-first century (Bailey and Clarke, 2000), 
The objective of knowledge management is to make appropriate knowledge available from providers to receivers when and where they needed. Knowledge providers and receivers could be internal or external to an organization. The traditional modes of sharing knowledge such as face-to-face meetings and printed reports continue to be useful, but in today's environment, knowledge must be accessible instantly when and where needed. Consequently IT can be used as an effective and efficient tool to enable tacit knowledge management, by capturing, sharing and applying the knowledge. It also provides tools to support management of explicit knowledge and also to support communities of practice. In other words, with knowledge management (KM) widely acknowledged to be of significant impact to business activities, it has resulted in a large number of $\mathrm{KM}$ tools for the corporate sector. Examples include the use of expertise access tools, e-learning applications, web portals, discussion and chat technologies, electronic message boards, synchronous interaction tools, and search and data mining tools.

Since most practical situations involve a combination of explicit and tacit knowledge, only an integrated set of IT tools can provide effective and efficient support to Knowledge Management (Sahasrabudhe, 2000). For example, specially, the adoption issues adjoining the deployment of Customer Relationship Management (CRM) solutions as an effective KM tool have attracted a great deal notice form the corporate sector. One reason cited was the high expenses involved in CRM implementation. CRM solutions have been extensively reported to be the fastest-growing category of enterprise applications for KM tools, with world-wide revenues projected to grow more than $50 \%$ annually to reach sales in excess of US\$67 billion by the end of 2005 (Toh, 2002). 


\section{In the Banking Sector}

In modem banks there is no debate about the value of Knowledge Management as a business practice. Banks, insurance companies and all other players in the competitive financial service sector have recognized that knowledge is power (Knowledge Management, 2001; Cross and Weller, 2001; Sorrentino, 1999). But the question is, how do they leverage that knowledge more effectively? The knowledge, in this sense, covers the range from the bank organisation's own internal intellectual capital, to the wealth of data held on any customer's transaction. However, the overall aim of the banking sector is to enhance their customer satisfaction and increase revenue as a result. One would have thought that this form of Knowledge Management was something that financial services companies were skilled in because of the service-based nature of their business. But this does not appear to be the case. Few banks or brokerages take knowledge management seriously, while a greater number of industrial companies do. Cross and Weller (2001) say that insurers have been more receptive to the benefits of knowledge management than the banking sector. The survey, conducted among top two hundred banks and one hundred insurance companies across Europe, found that while thirty percent of the overall respondents were not considering implementing a knowledge management programme, their number included only one insurer. Despite this, they warned that two thirds of European Banks are failing to exploit their intellectual capital effectively by not having a knowledge management strategy in place. In fact, skill at knowledge management has become a critical competency for banking sector survival in the 21st centaury. Whether or not a bank has formally recognized the importance of knowledge management by creating their internal environment, such as appointing a 
chief knowledge officer, the fact is that every organization needs a person or persons to watch over and manage the creation, storage and dispersion of knowledge (Sorrentino, 1999). These personnel should also be responsible for the creation and implementation of strategy that generates value from organizational knowledge.

\section{How can banks achieve good knowledge management practices?}

Usually, information builds on data and knowledge, knowledge builds on both data and information and Knowledge Management includes all these three elements. It does not focus only on databases or information technology, although it may use both. Its concern is with managing its knowledge assets: creating, storing, protecting, disseminating and using mission-critical knowledge. When people need knowledge, is it the right knowledge and is it timely and easy to locate and access? Is this precious commodity updated as learning occurs and better ways of doing things are discovered?

Sorrentino (1999) has suggested applications of the Knowledge management model made by Michael Earl. She argues that the approach introduced by Earl can be useful to represent knowledge management components such as Knowledge systems, Networks, Knowledge workers and Learning organizations in the banking sector. She pointed out that a bank as a whole have must of these four key components, but each institution highlights a different combination of them. The hard indicators such as IT infrastructure, databases, software applications are usually well developed because banks are heavily dependent on IT and cannot survive without it. On the other hand, the soft ones i.e. human resource 
development, promotion of cross-functional learning culture, cultivation of skills are often scattered or lacking. In addition she has pointed out that in banks there is no debate about the value of Knowledge Management as a business practice. Nevertheless, the current situation shows the banks are beginning to recognize the relevance of knowledge management as a competitive differentiator and professional core competencies.

The most common fields of knowledge management applications in a bank are risk management, marketing management, customer relationship management and performance measurement especially for the benefit of its stakeholders (Marshel, Prusak and Shillberg, 1997). Usually, in major banks investments in Knowledge Management systems such as Decision Support Systems, Data Warehouses and Data Mining are rapidly growing. It is a first attempt to capture and share information (even if this knowledge is closer to the explicit kind than the tacit), creating an environment, which promotes the transfer of knowledge. Also bank's core competencies are beginning to be considered a valuable asset.

In the banking sector, it is especially emphasized that Customer Relationship Management (CRM), which includes marketing and presentation components is essentially about Knowledge Management (Gary, 1999). In order to sort out and track relationships overtime and through transactions, it is necessary to focus on two things.

- Banks have great deal of knowledge about their customers

- But they have a great difficulty in putting that knowledge to practical use in all encounters with an individual customer 
In Knowledge Management systems, the large amount of instructed information that exists in banks may be useful when put into specific contexts. Neural Network Technology can be used to identify patterns in consumer behavior that can help banks to exploit cross-selling to other needed services, says the Marketing Director at Autonomy (Young, Kung (1999). Additionally, this type of technology in Knowledge Management systems will allow for tacit knowledge of employees to become explicit so faster decisions can be made, and more innovative products and services can reach markets more quickly.

Although there are many Knowledge Management activities in the banking sector, the Knowledge Management Magazine (2001) says "You cannot use Knowledge Management techniques to improve customer service and boost the bottom line until you can share that knowledge effectively and efficiently".

\section{Current Situation}

Cross and Weller (2001) put forward some findings based on a survey of 300 European banks and insurers and they highlight poor understanding, conservative approach, cultural rather than technological approach, a grass roots approach and a focus on paper documents have been affected to the delay of development of Knowledge Management in banking sector. In addition they report it is too early to tell whether KM is effective, but it is necessary to improve knowledge sharing, to obtain financial and customer-related details, and to retain intellectual capital. Furthermore it reveals that communities of interest, followed by Internet, 
are the best ways of sharing knowledge; and lack of understanding is the greatest barrier.

Some banks have already created structures within firms to facilitate the flow of knowledge. For instance NatWest Markets has created "knowledge map" showing where knowledge resides within the organization, and how 'knowledge coordinators' can locate it and keep it moving (Notes:. 1997). The main focus of the initiatives is the newly centralized training and development facility, the new learning organization (NLO). In addition the KM capability is internet based, providing a sharing tool for staff employed by NLO in six sites throughout the United Kingdom and providing service to five NatWest business units (Abell and Oxbtow, 2001).

Another important component in Knowledge Management is intellectual capital, a mysterious value, which lies between book value and market value of an organization. Some banks have recognized the importance of the hidden value of intellectual capital in knowledge management. For an example, Canadian Imperial Bank of Commerce (CIBC) has became one of the world's first banks to dedicate a whole lending division to businesses whose primary assets are innovation and knowledge (Darling, 1996; Dzinkowski, 1999). They also have recognized that to become learning organization, the rate of learning by individuals, teams and corporations must be equivalent or even exceed the rate of change in the external environment.

Silicon Valley Bank has launched eSOURCE which is a web site that supplies customised business intelligence and resources to customers, helping them to grow their fledgling enterprises (Nelson, 1999) This coalesces client profiles with advanced knowledge management 
capabilities and a user profile to tailor content for each user. Therefore, people can access this knowledge base since it covers many industry sectors, or just their personal knowledge base including investment banking, cash management, funding sources, real estate and facilities, relocation, risk management, human resources, employee benefits and recruiting.

In addition, there is much evidence for the adoption of intranet technology as a vehicle for encouraging organization-wide knowledge sharing within banks. The intranet helps to make stronger the existing functional and national boundaries with 'electronic fences' (Newell, Scarbrough and Swan, 2001). This intranet can be described as an interactive and decentred technology, which therefore has the potential for multiple interpretations and effects. In fact it enables processes of communication, social coordination and collaboration. This was evidenced by the fact that none of the independent intranet-implementation projects considered actually managed to encourage knowledge sharing as intended, even within the relatively homogenous group for which it was designed.

\section{Trends}

The adoption of knowledge management among European banks is in its infancy. According to an IDC survey (2000), only $20 \%$ of western European banks are currently using knowledge management applications. They' expect that this situation will be changed without delay; as a result Knowledge Management will become priority in the banking sector. 
Due to increasing competition, European banks are ramping up efforts to implement knowledge-based systems that could link people to people, and people to knowledge.

According to the document synopsis of IDC (2000), IT spending on knowledge management systems in the European banking sector will amount to $\$ 514.4$ million in 2004 . Further more, it states that IT spending on knowledge management will be high in some European countries such as France, Germany, Italy, the Netherlands, Sweden and the United Kingdom and will contribute four fifth of the total IT spending in the western European banking sector. The fastest growing countries are expected to be France, the Netherlands, and Sweden and the United Kingdom and Germany will also record the highest levels of spending on Knowledge Management in the future.

On the other hand "Virtual Banking" is an ongoing effort by the banking industry to automate banking services for its internal and external customers. The application of technology and knowledge is its main method of achieving this transaction. Bank customers are allowed by these applications to perform "virtually" every type of transaction available at their bank without visiting a physical banking structure each time.

Banking organizations are also moving towards new organizational models, emphasizing radical decentralization, coupled with advanced IT that allows them to tap into its intellectual assets. This approach is used by some banks in the Netherlands in a Knowledge Management practice 
initiative that allows measuring at a high level of abstraction the intellectual capital of the company (Dekker and De Hoog, 2000).

\section{Conclusion}

In order to start to try and convince the sceptics that knowledge management is indeed important to organizations' continued success it is advisable to try and generate discussion and thinking about the basics of knowledge itself, the different types, tacit, explicit and how it differs from information and data. Once this has been achieved the way in which knowledge management can fit into the business units or the organization can then be thought out.

One recurring theme of much of the knowledge management related literature referred to in this paper is that there is no debate about the value of knowledge management as a business practice in banking industries. However, most banks do not take it seriously, except for the Information Technology while a greater number of other companies do. Banking is an information-centered activity and it is a vital requirement to make information and knowledge available at right time in the right place without delay. The other notable fact is at Knowledge Management experience in banks pinpoints four key elements of management namely individual learning, team learning, organizational learning and customer learning. In conclusion, with the KM practicing and applications used in the Banking sector, it is ostensibly clear that the benefits of KM solutions should no longer be limited to larger global banking institutions, it would easily be applied by the smaller banking organisations in developing countries such as Sri Lanka with deep pockets for IT tools and applications. The effective KM adoption could lead to better return on 
investments and finally all sectors of banking industries will gain a lot as a new source of competitive advantage.

\section{References}

IDC (2000). "Document synopsis. Implementation Strategies for Knowledge Management in Banking; Part 2: Analysis of Competition". [online]. http://www.idc.com!getdoc. ihtml?containerId=MBO1Ga. [Accessed 13

November, 2001]

Abell, Angela and Oxbrow, Nigel (2001). Competing with knowledge: the information professional in the knowledge management age. London: Library Association Publishing

Bailey, Catherine and Clarke, Martin (2000). "How do managers use knowledge about knowledge management?". Journal of Knowledge Management, 4(3), 235- 243

Barclay, O. Barclay and Murray, Philip C. (1997). What is knowledge management? .VA:Media Access Group[online]. htto://www.mediaaccess.com!whatis.html. (Accessed 22 January 2002)

Cross R, Weller S (2001). "Winning through knowledge (knowledge management in banks)". Financial World, (UK), 19 March, 31

Darling, Michele S (1996). "Buildıng the knowledge organization". Business Quarterly. 61(2). 61-66 
Dekker, R annd De Hoog, R (2000). "The monetary value of knowledge assets: a micro approach" . Expert Systems with Applications, 18(2),111124

Dzinkowski, Ramona (1999). "Managing the brain trust". CMA Management. $73(8), 14-18$

Gary, Abraman (1999). "Customer KM". CIO Enterprise, 12(15),66

Knowledge Connection (1999). Knowledge management [online] London:David Skyrme Associates. http://www.skyrme.comlkm.htm. [Accessed 23 January 2002]

Knowledge management (2001) . Cover Story: Piggy in the middle. [online]. Reading:Bizmedia. January 28. http://www.kmmag.co.uk/OCTOO/COYER.HTM [Accessed 2 January, 2002]

Macintosh, Ann (1999). Knowledge management [online]. Edinburgh: Artificial Intelligence Applications Institute http://www.aiai.ed.ac.uk/ alm/kamlnks.html\#apProach (Accessed 20 January 2002)

Malhothra, Yogesh (2001). Knowledge Management for the New World of Business. [online]. New YorkBRINT Institute. http://www.brint.comlkm/whatis.htm. [Accessed: 11 November, 2001]

Marshel, C, Prusak, Land Shillberg, D (1997). Financial risk and the need for superior knowledge management. In Prusak, L(ed.).Knowledge in Organizations, Butterworth- Iteinemann: Boston 
Murray, P and Myers, A (2006). "The knowledge barrier". Information Strategy, 2(7),26-33

Nelson, Kristi (1999). "Silicon Yalley Bank arms dients with online business intelligence". Bank systems and technology, 36(8),46

Newell, S ; Scarbrough, H and Swan J (2001). "From global knowledge management to internal electronic fences: contradictory outcomes of intranet development". British Journal of management. 12(2).97-111 (12)

Nonaka, I (1991). The knowledge creating company. Harvard Business Review. 69(6),96-104

Oxford Advanced Learner's Dictionary of Current English (2000). 6th ed. Wehmeier, Sally (eds.). Oxford:Oxford University Press, 714

The Banker (1997). "Notes: CSFI: knowledge bank: how can banks and other financial services companies market more use of the information they hold?". The Banker, 147(862), 15

Toh, A. (2002). "Sawadee CRM!", CIO (October 2002), International Data Group IDG), Singapore.

Sahasrabudhe, Vitas (2000). Information Technology in support of knowledge management. In: Srikantaih, T. Kanti and Koenig, Micheal E.D(ed.). Knowledge management for the information professionals.pp.269-276. New Jersey: Information Today 
Sorrentino, Maddalena (1999). "Notes on Knowledge Management in banking". In KIO Meeting. [online], 24 September 1999. Barcelona:Spain http://www.sistemi-informativi.org/kio/cons/KIOmeetBarRTF.htm (Accessed 15 November 2001)

Srikantaiah, T. Kanti (2000), Knowledge management: afaceted overview. In: Srikantaih, T. Kanti and Koenig, Micheal E.D(ed.). Knowledge management for the information professionals.pp.7-17. New Jersey: Information Today Stewart, T.A, 1997, Intellectual Capital, The New Wealth of Nations, London :Nicholas Brealey.

Young, Kung (1999). "Technology: a learning process: Neural networks can mimic the human brain". The Banker, 149(875), (13) 